\title{
Excellence through Value Education - A Case Study of Sharada Vidyanikethana Public School
}

\author{
Gururaj Ganapati Gouda ${ }^{1}$, \& Laveena D’Mello² \\ ${ }^{1}$ Research Scholar, Srinivas University, Mangalore, Karnataka, India. \\ Email: gururajitgi@gmail.com \\ ${ }^{2}$ Assistant Professor, Social Work Department, Srinivas Institute of Management Studies, \\ Mangalore, Karnataka, India. \\ Email: lavynoronha@gmail.com
}

Type of the Paper: Case Study.

Type of Review: Peer Reviewed.

Indexed In: OpenAIRE.

DOI: http://doi.org/10.5281/zenodo.2558062.

Google Scholar Citation: $\underline{\text { IJCSBE }}$

\section{How to Cite this Paper:}

Gouda, Gururaj Ganapati, \& D’Mello, Laveena. (2019). Excellence through Value Education - A Case Study Vidyanikethana Public School. International Journal of Case Studies in Business, IT, and Education (IJCSBE), 3(1), 9-19.

DOI: http://doi.org/10.5281/zenodo.2558062.

International Journal of Case Studies in Business, IT and Education (IJCSBE)

A Refereed International Journal of Srinivas University, India.

(C) With Authors.

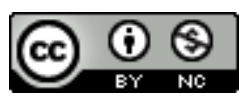

This work is licensed under a Creative Commons Attribution-Non Commercial 4.0 International License subject to proper citation to the publication source of the work.

Disclaimer: The scholarly papers as reviewed and published by the Srinivas Publications (S.P.), India are the views and opinions of their respective authors and are not the views or opinions of the S.P. The S.P. disclaims of any harm or loss caused due to the published content to any party. 


\title{
Excellence through Value Education - A Case Study of Sharada Vidyanikethana Public School
}

\author{
Gururaj Ganapati Gouda', \& Laveena D’Mello ${ }^{2}$ \\ ${ }^{1}$ Research Scholar, Srinivas University, Mangalore, Karnataka, India. \\ Email: gururajitgi@gmail.com \\ ${ }^{2}$ Assistant Professor, Social Work Department, Srinivas Institute of Management Studies, \\ Mangalore, Karnataka, India. \\ Email: lavynoronha@gmail.com
}

\begin{abstract}
Today education has become industrialized and it is limited in the teaching of concept printed in the book. At the same time, inappropriate understanding of the teaching profession has made students be away from value based education system. India is a country of unique culture, tradition and its deferent leaving style of citizens, getting step by step modified in connecting thisvalue of life among civilians. High influence of western lifestyle, the growth of urbanization and technological development is making the young population of India lose an opportunity in adopting the value-based lifestyle, empathetic behaviour and respective attitude in their day today's leaving. The other hand unchanged Indian education system is also playing major role behind deciding the future of its young generation. This may affect the value based social system of tomorrow. Sharada Vidyanikethan Public School, Administrated by Tulunaadu Educational Foundation is one of the schools providing valuebased education with modern facilities in India. The case study is exploring the benefits of value-added education in preparing students population as well trained and equipped with human values, character, moral integrity, and the knowledge and skills to be good citizens of a particular country.
\end{abstract}

Keywords: Schools, Students, Values, Education.

\section{INTRODUCTION :}

Sharada Vidyanikethana Public School is one of the schools providing value-based education with modern facilities in reaching the demands of young student's generation in India. This school is deferent from other schools, because of its deferent system of education and nurturing the children [1]. Values education and moral education is to help young students grow up with good values, character, moral integrity, and the knowledge and skills to be good citizens of a particular country. Character education is also one of the important systems of nurturing to create schools that foster ethical, responsible and caring young students by modelling and teaching them a good character. It is a responsibility of schools, districts and states to instil in their student's important core ethical values such as caring, honesty, fairness, responsibility and respect for self and others. Good character or value added life will no be formed automatically; it is developed over time through a process of teaching, example, learning and practice. It is developed through value education [2]. This comprehensive method utilizes traditional and emotional approaches by the qualified teachers for inculcating and modelling values, and for teaching and demonstrating to young people the best values and moral traditions of their culture. This value-based education system is made to develop the attitudes, beliefs, and skills to guide their own lives and make responsible, personal decisions in a changing world [3]. Teachers and school work as a source of variance in student'soutcomes [4]. Value education has made positive changes in the students in classroom behaviour and interaction with others. Schools and teachers are effective tools in the way of empowering students [5]. 


\section{OBJECTIVES :}

Value-added education is one of the important tools in shaping the student's personality. Every educational institution should look into adopting student centred classroom teaching with value principals. To identify the several dimensions of value education, the following objectives are been discussed.

(a) To identify the deferent values inculcated in the education system of SVPS

(b) To identify the benefits of value-added education

(c) To explore the strengths and priorities of SVPS

(d) To explore the method of nurturing in SVPS

(e) To know about employee development programmes in SVPS

\section{HISTORICAL BACKGROUND OF SVPS :}

Sharada Vidyanikethana Public School initiated in the year of 2007, founded and led by Tulunadu Educational Trust. The founder president Prof. M. B. Puranik with his all effort and guidance of trust members initiated a new educational system to ensure that traditional and progressive methods of learning harmonize with each other and bring out the best in every child.

\section{VALUES THOUGHT IN SVPS :}

Character or value based education holds several principles, that there are widely shared and important ethical values such as caring, honesty, fairness, responsibility, and respect for self and others that form the basis of good personality in students [6]. Sharada Vidyanikethana Public School committed to Value education explicitly names and publicly stands for these systems; promulgates them to all members of the school and also to the community; defines them in terms of behaviours that can be observed in the life of the students; SVPS models these values included in its education system; studies and discusses them with outer world and uses them as the basis of human relations in the school among the students as well as teachers; SVPS also upholds all the values by making all school members accountable to standards of values. Value differences between age, sex, and groups and values of special groups such as students and emphasizes particularly the "importance of values" and how different value systems interact with each other [7]. Due to the modernization and urbanization today's young population has no opportunity left to inculcate a life values in their personalities, lead a healthy life, been accepted by the social system, identified by human society and play the important role of son or daughter, student or friend and at least a good citizen of their own country [8]. SVPS will stand as a unique educational institution for its value-added educational system in nurturing and educating its students' as good and positive contribution to the society. This is also Training them to be able in their life to face the challenges and helping them to adopt good and smooth behaviour. This educational institution mainly works on some value principles they are.

(1) Aksharabhyaasa :

As per Hindu religious belief, the institution will bring the child and its family together in Aksharabhyaasa programme to make the baby initiate the education by writing Omkaara on the plate filed by rice as per the instruction of priest.

(2) PrathaSmarane and Pranayama :

Sharada Vidyanikethana Public School also adds another method of education into its value system in making the students be strong in their psychology and be able to deal with the competition and complication at the future life. Every day at early in the morning the students will gather in a hall called "Dhyaana Mandir" and has a mass prayer. After the prayer pranayama will be practised by the students. Yoga is one of ancient Indian discipline of bringing balance between the physical, emotional, mental, and spiritual dimensions of an individual. The meditation will benefit the students in reducing anxiety, depression, hostility, anger, and overall stress [9].

(3) The Practice of Yoga:

Every day student are encouraged and compulsorily thought Yoga. By teaching yoga, Sharada School is strengthening the mind and body of the students which motivates the self-esteem of the students and help them to adopt a healthy and simple lifestyle. In this context, we describe the implementation of Hatha Yoga in the Mindfulness-Based Stress Reduction [10]. 


\section{(4) Shabojana:}

Students in Sharada Vidyanikethana Public School will sit together and have their food. During this time they all chant "Bhojana mantra" and respect the food. By these students are made to understand the importance of food. Also, students are encouraged to save food and water.

(5) The Practice of Bhajan:

In the evening all students gather in a hall and chant Bhajan in front of the idol of Goddess Saraswathi. This is also an important time which inculcates all the traditional values in student's life and helps them to explore themselves. Through this bhajan, the students will learn the importance of respecting elders and each other. Prayer is an ancient healing practice not generally available in our health care system [11].

\section{PANCHA MUKHI OR FIVE-FOLD EDUCATION :}

Values education includes moral principles more in terms of promoting self-awareness and selfcaring. Value education also helps students learn a highly systematic, step by step process for making moral decisions according to situations. The overall aim of the moral development approach is to help the students to think increasingly clear and comprehensive ways [12]. Sharada Vidyanikethana Public School has its own philosophy in providing value education. This system has five deferent folds that are called Pancha Mukhi Shikshana which are as below.

\section{(1) Annamaya Kosha:}

This fold of education mainly works to provide good health and wealth through several physical activities to make students stay physically fit and healthy. So deferent fitness programmes like Yoga, Taekwondo, Aerobics, and Sports and games are provided for the students.The more physical activity, greater the health benefit. Continues of physical activity can bringlots of health benefits in students with several problems. To achieve substantive health benefits, physical activity is one of the best methods used by SVPS [13].

\section{(2) Pranamaya Kosha:}

This type of education only to enhance the overall personality of the students through Meditation and Bhajans. Students are nurtured with several personality enhancement programmes to strengthen their inner stimulus towards adopting good personality. Meditation has the potential to decrease anxiety, stress, depression and many other psychological problems and it strengthens students emotional condition to stay active and motivated [14].

\section{(3) Manomaya Kosha:}

Manomaya education will provide a wide range of opportunities to the students to learn and enhance the fine arts like Dance, Drama, Music and Arts. Developing a keen sense of appreciation in the above arias is a priority in SVPS. The positive effects ofextracurricular activities on students are good behaviour, better academic grades, successful school completion, and positive aspects to becoming successful adults, and adopt a good nature of being [15].

\section{(4) Vignanamaya Kosha:}

Sharada educational institution will also give priority in providing a practical type of education for the students to have a better understanding of the theoretical subjects. So that students feel free to write exams without fear and score better academic score.

\section{(5) Anandamaya Kosha:}

SVPS also provides an opportunity to its students to learn through the enjoyment from the outer world. In this students get an exposure to visiting deferent places through picnics and outings with teachers and their peers. The results reveal that the extended opportunity to the students in involving the outer world had the potential to improve social relations and social participation, collaboration and better communication [16].

\section{SYSTEM OF NURTURING IN SVPS :}

Each school may have a differential effect on the performance of different types of students [17]. SVPS is one of the rarest institutions providing value-based education with modern facilities. This institution tries to reach the need of new student's generation by providing modernized classrooms with technologies such as smart board, computer, tab learning, etc. Good and quality lodging, healthy food, all the way encouragement to sports, curricular and extra-curricular activities are also included 
in this system. At the same time, SVPS also creates an environment where students understand and adopt the importance and saviour need of humanity, love and care, unity and respect, many more. SVPS builds self-respect and respect towards others in its students. Through several organized programmes it promotes patriotism in students and also motivates the students to carry the culture and traditional values in their life through.

(1) The Importance of Culture and Tradition:

SVPS highly believes in cultural and traditional values which have the capacity to organize its people. So here students are also given continues opportunities throughout the academic year to participate in several programmes which promote India's uniqueness and greatness. Participating in various festivals students enjoy and learn the traditional importance by involving in all the activities conducted in school.

(2) Education of Agriculture and Horticulture:

While there are concerns about the youth population of India drifting away from agriculture, SVPS began teaching farming compulsorily to classes $5^{\text {th }}$ to $10^{\text {th }}$ from 2018 and 19 academic years. This school appointed well trained and experienced teachers in making the student have expertized training in practical as well as theoretical knowledge of farming. Through this, the institution is bringing a trend for its students of involvement in growing own food and experience the struggle behind satisfaction of our hunger every day.

(3) Creating Patriotism and a Sense of Social Responsibility:

SVPS play the major role in bringing students into the track of social responsibility and contribution to the Nation. Throughout the academic year school is organizing several programmes, workshops and special education for the students in encouraging them to understand their social responsibility being citizens of their country, member of family, leader of a team, student of a school etc. student social responsibility is not only a valued outcome in and of itself but that can be instrumental in the acquiring of knowledge and the development of their abilities [18].

\section{(4) The System of Kreedakula and Gurukula:}

Sharada has setup with two deferent platforms for its students by identifying their field of interest and expertize. These two platforms called as Gurukula Paddati and Kreedakula Paddati. This mainly helps the students to select and get expertized knowledge and training in their area of interest or skills they have. Gurukula mainly focuses on academics, it encourages the students to have specialized teaching and motivation towards their academic goal. Kreedakula focuses on specialized coaching of sports. As per the student's interest and skills, they are selected and given everyday training in morning and evening.

\section{(5) Encouragement to the extra cultural activities:}

Not only academics SVPS also encouraging the students for extracurricular activities such as Drama, Dance, Music, Art and Craft and many more. Students are given opportunity in several special skills which promote them into active and skilled personalities and life leaders[15].

(6) Importance to the experiential learning:

Through several activities based on curriculum and area of training, SVPS is giving importance in providing an opportunity to its students to have learned through experience. Multiple ways of teaching both in the classroom and outer world are used. Visual, auditory and practical methods in teaching are used in making students have a better understanding of the knowledge.

\section{MAN POWER SETTING IN SVPS :}

The organizational man power setting chart is shown in figure 1. It gives an idea on how the powers are planned and delegated systematically for optimum decision making. 


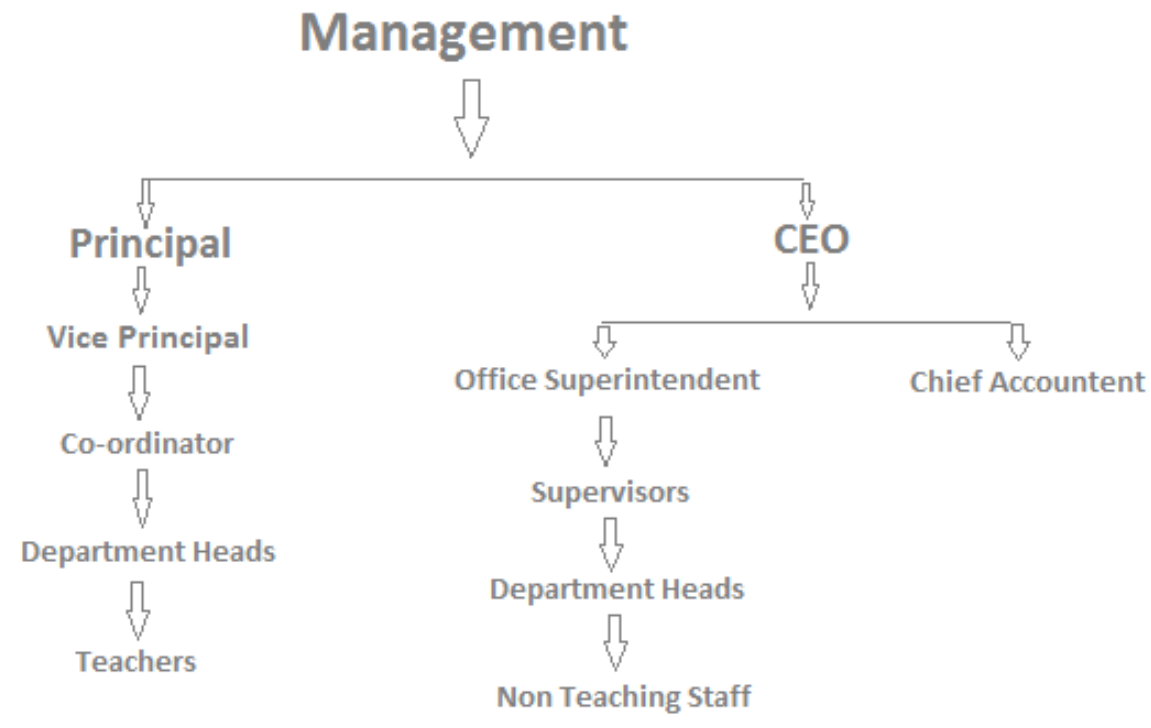

Fig. 1: Manpower setting in Sharada Vidyanikethana Public School

\section{EXPLORING NEW POSSIBILITIES IN SVPS :}

Availability of free land space: SVPS School has expendable availability of land in its campus for any further extension of infrastructure. Present this school is using the land for cultivation of vegetables in teaching its students on agriculture and horticulture. Some part of the lands are also used for sports training and extracurricular activities. SVPS can extend its buildings for any of its future purposes.

Availability of skilled \& qualified manpower: SVPS has skilled and qualified manpower available for any of its actions. Around $75 \%$ of employees are accommodated within the campus premises and they are available at any time for the work of the school. The other hand the employees working in this school are maltytalented and can contribute to the multiple arias of its work. These skilled and qualified employees can be used for the further development of the school and to bring the best outcome in students [19].

Availability of peaceful environment: SVPS located around 18 kilometres of distance from Mangalore city and around 4 kilometres from national highway. The area in which school located has village environment surrounded by good nature, without high sound disturbance, dust, etc. This good and peaceful environment is one of the possibilities in this school to increase the learning interest of the students and provide a healthy learning environment.

Experience in the education sector: The management of Sharada Vidyanikethana Public School has around 25 years of experience in serving in the field of education. Its majority of employees are serving in this institution from the year school started. These management and employees have great experience of dealing with several problems of competition in the educational sector, challenges of holding the grip in continuation of service and dealing the students with several problems. These experiences are the strong pillars for the confidently taking up the decision in the expansion of further steps such as starting several UG and PG courses, leading institution towards making it as a university.

Free space in classrooms: The school has flexible classrooms having the ability to accommodate a minimum of 50 students in each class. Classrooms are made with full of ventilation from nature, free breathing space, smart boards, lockers and free space for activities. These classrooms are another area in which full of activities based curriculum can be planned to nurture the students. Provide them with an interesting class for the better understanding of the teaching to improved output. Teachers are responsible for knowledge of where students are and where they need to go; having knowledge into students' special needs and progress. In choices of curricular and extracurricular activities, govern children's participation; reach the expectations from parents these classrooms are going to be the places were teachers can play an important role in nurturing students [20]. 
Agriculture, Horticulture and Farming: a larger area of land available within the SVPS campus can be utilized for farming such as fish farming, sheep farming, cow farming, mushroom farming, rabbit farming or any fruits farming which is suitable for the particular area and soil. These type of farming also can be included as part of the curriculum in teaching the students theoretically as well as practically. This is been noted that the present education system is not supporting the development of the agriculture industry in India. SVPS can take further more steps in providing agriculture education aiming the improvement of the country which ultimately will bring national development as well as the growth of people [21].

Physical assets of the campus: SVPS has a beautiful campus with a natural environment. For the growth, the physical assets of the particular organization will play a major role. In the educational sector the environment and appearance of the campus also an important area were students adopt certain positive qualities and feel free and motivated to learn. SVPS can focus in giving an attractive and healthy shape to the campus through converting empty area as a garden, convert dusty sports ground as grassed sports ground, construct or alter infrastructure as an attractive one and create an opportunity for the students to get at least one day in a week to sit outside the classroom in open garden and have learning.

Provide expertized teaching in several arias: SVPS has well trained and qualified teachers and non-teaching staff. These are engaged in multiple works, in which they are not specialized or trained. This type of work plan is affecting the area that they are specialized, to get the best result. Such a situation makes the employee get blocked or disturbed in responding to or involving himself into multiple areas of work in which he or she is not interested or trained. Such a situation will also disturb the area in which he or she is specialized. So School can give more importance to the employee's area of expertize so that they feel free and can make the maximum effort in bringing a high level of achievement in their particular area [22].

Health education as part of the curriculum: "Sharada Ayurdhama" Hospital attached to Sharada Vidyanikethana Public School campus can be utilized for teaching students on health. School can adopt health education as its curriculum and provide regular class as oral and practical. So that students of SVPS get an extended experience of adopting a good and healthy lifestyle, this type of education also increase the possibilities of increased social responsibility and self-care in students. Educational institutions are considered to be very important places for health education for children and adolescents. The field of health education in schools is a greater opportunity for the students to adopt basic knowledge who are interested in doing MBBS [23].

Character Education and Leadership training: SVPS environment, opportunities provided for the student's, infrastructure and manpower available are cooperative for any new initiation in the campus. This School also can think of introducing a specialized course on Character education and leadership training as part of its curriculum. This is going to be the first and new opportunity created in India for the students to get explored in future leadership and social administration [24].

\section{FACULTY TRAINING AND ENRICHMENT :}

Well trained employees are the real pillars of any organization; SVPS is working more in training its employees through several human resource development programmes.

Workshops: SVPS is organizing and encouraging all the faculties to undergo several workshops organized by deferent organizations, inside and outside the campus. The teachers who attend such workshops are provided all the allowances. So teachers are updated, skilled and motivated towards better contribution to the school and develop professional self [25].

Spatial education programs: SVPS also encouraging both the teachers and non-teaching staffs to undergo several education programmes on their specialized arias, such as mathematics skills training, social science conference, language development programme etc.

Provision of mental health counselling: School counsellor helps students familiarize themselves with the problem-solving process [26]. School is also providing both individual and group counselling for its employees. Sometimes resource personalities are called periodically for special sessions which helps the teachers, as well as students, find deferent ways to come out of several problems. 
Annual teachers training camp: SVPS is conducting a teachers training camp every year in deferent places for its teachers. Invited specialists will take-up the class on deferent topics including personality as well as subject related activities, these activities will help the teachers to have a better mutual understanding, develop cooperation among them [25].

\section{STRENGTHS OF SVPS :}

SVPS has a deferent and unique working strategy and method of nurturing of its students. Expandable campus, flexible classrooms, big and equipped sportsarena, hardworking teaching and non-teaching staff, well supportive management are the real strength of the school. Ability in taking any challenges with high involvement of its employees is a great contribution behind the success of the school.

\section{CHALLENGES :}

The Indian education system is facing serious challenges in providing quality education and nurturing of students. These include the infrastructure of comparable quality, improving output, efficiency, and effectiveness of the working strategy. In recent years, there has been a considerable emphasis on decentralized leading team and influence of community in the school's education system; the outcome is not as expected. This is happening due to the inadequate planning and lack of managerial and professional competencies at various levels [27]. Tensions experienced by the teacher in handing over greater classroom control to pupils. Child-Centred ideas in the classroom have to be planned in teacher-training programmes and school with the intention of creating more child-friendly, democratic learning environments [28].

India is providing several opportunities for its people in the education sector to achieve $100 \%$ literacy by adopting new policies and programmes. This change in the education sector is increasing the computation in this sector among institutions. Many new educational institutions are getting started and these institutions are focussing on making themselves unique and qualitative then others. To have the success they are working on their teaching strategies, manpower setting, and new development plans. The other hand demand of the new generation is been changed also their interest and complicated nature is highly challenging to deal is another threat for the unchanged educational institutions. The most important predictors of student's satisfaction with the school are teachers. Student's feeling that they are treated in a friendly way; they feel safe and believe that teachers are supportive. The study suggests that in school attention should not be only given only to classroom teaching materials but also to the quality of a student's school experience and the quality of the relationship with the teachers [29].

\section{SUGGESTIONS FOR FURTHER IMPROVEMENTS :}

The goals of educational institutions and educational professionals not only to prioritize academic learning, but they should also focus on social, emotional, and ethical competencies. Social-emotional skills, knowledge, and dispositions provide the foundation for getting acceptance in the society, participation in a democracy and improved quality of life. Best value practices and academic policy in relation to creating a safe and caring school climate, home-school partnerships, and a pedagogy informed by social-emotional and ethical concerns are recommended to create student centred educational environment. SVPS is suggested that students must be rewarded when they are "caught" being good [30]. The importance of scientifically sound measures of social-emotional and ethical learning and advocates for effective teaching and learning environment between school and students to develop authentic methods of evaluation is one of the effective practices recommended for SVPS. The evidence-based guidelines for social-emotional learning, which are being increasingly adopted by the deferent schools. Social, emotional, ethical, and academic education is a human right that all students are entitled [31]. Especially during a period of school restructuring, the educational administrator needs to consider their responsibility to promote an ethical environment in their schools [32].

SVPS can think of centralizing the responsibilities and stop the involvement of deferent people in leadership. A working strategy should be updated; adoption of new policies, changes in employment planes and goals are also will contribute to the success of the school. Unskilled employees and usage 
of qualified employees in multiple arias in which they are not qualified or trained and lack of employee's development and enrichment will cause the institutional growth and good output. Better utilization of available resources, such as the support of management, equipped employees, and physical asset of the campus will contribute to the overall growth of the institution. Lack of stability and strength in leadership of working with planes or achieving success may disturb the smooth functioning of the school. Teaching to student's learning levels are highly-cost effective at increasing learning, as are reforms that improve accountability and incentives, such as local hiring of teachers on short-term contracts. Technology could potentially improve pedagogy and their accountability [33].

\section{CONCLUTION :}

Education included with several values and intention of nurturing students to make them as good personalities are one of the main aims of SVPS. The school is making all the possible efforts in helping its students have a great educational experience with a good academic result. However, this school has taken initiation in motivating other schools to look deep into adopting values-based approaches towards their students in nurturing. Values are the most important aspects in every individual's life to accept society and been accepted by society. So value based curriculum is one of the essential parts of education in today's society.

\section{REFERENCES :}

[1] Ryan, K., Bohlin, K. E. (1999). Building Character in Schools: Practical Ways to Bring Moral Instruction to Life. Jossey-Bass Inc., Publishers, CA 94104.

[2] Pala, A. (2011). The need for character education. International Journal of Social Sciences and Humanity Studies, 3(2), 23-32. DOI: http://dergipark.gov.tr/ijsshs/issue/26222/276136

[3] Kirschenbaum, H. (1995). 100 Ways to Enhance Values and Morality in Schools and Youth Settings. Allyn \& Bacon/Simon \& Schuster Educational Group, MA 02194-2310.

[4] McCaffrey, D. F., Lockwood, J. R., Koretz, D. M., \& Hamilton, L. S. (2003). Evaluating ValueAdded Models for Teacher Accountability. Monograph. RAND Corporation.CA 90407-2138.

[5] Srikala, B., Kishore, K. K. (2010). Empowering adolescents with life skills education in schoolsSchool mental health program: Does it work?. Indian Journal of psychiatry, 52(4), 344.

[6] Lickona, T. (1996). Eleven principles of effective character education. Journal of moral Education, 25(1), 93-100. DOI: https://doi.org/10.1080/0305724960250110.

[7] Feather, N. T. (1975). Values in education and society. Free Press. DOI: http://psycnet.apa.org/record/1976-12049-000.

[8] Lickona, T., Schaps, E., \& Lewis, C. (2002). Eleven principles of effective character education. Special Topics, General. 50. DOI: https://digitalcommons.unomaha.edu/slcestgen/50.

[9] Chaddha, A. (2015). Breathing slower to live longer. Journal of Indian College of Cardiology, 5(3), 183-188. DOI: https://doi.org/10.1016/j.jicc.2015.04.005.

[10] Salmon, P., Lush, E., Jablonski, M., \& Sephton, S. E. (2009). Yoga and mindfulness: Clinical aspects of an ancient mind/body practice. Cognitive and Behavioural Practice, 16(1), 59-72. DOI: https://doi.org/10.1016/j.cbpra.2008.07.002.

[11] Ameling, A. (2000). Prayer: an ancient healing practice becomes new again. Holistic Nursing Practice, 14(3), 40-48.

[12] Hersh, R. H. (1980). Models of Moral Education: An Appraisal. DOI: https://eric.ed.gov/?id=ED187641.

[13] Janssen, I., \& LeBlanc, A. G. (2010). Systematic review of the health benefits of physical activity and fitness in school-aged children and youth. International journal of behavioural nutrition and physical activity, 7(1), 40. DOI: https://doi.org/10.1186/1479-5868-7-40. 
[14] Seppala, E. (2015). How meditation benefits CEOs. Harvard Business Review.

[15] Massoni, E. (2011). Positive effects of extracurricular activities on students. Essai, 9(1), 27.

[16] Fagerstam, E. (2012). Space and Place: Perspectives on outdoor teaching and learning. Linköping University Electronic Press.

[17] McPherson, A. (1993). Measuring added value in schools. Education Economics, 1(1), 43-51.

[18] Wentzel, K. R. (1991). Social competence at school: Relation between social responsibility and academic achievement. Review of educational research, 61(1), 1-24. DOI: https://doi.org/10.3102/00346543061001001

[19] Darling-Hammond, L., \& Berry, B. (2006). Highly qualified teachers for all. Educational Leadership. $\quad$ 64(3), $14 . \quad$ DOI: http://www.ascd.org/portal/site/ascd/template.MAXIMIZE/menuitem.

[20] Aithal, P. S. (2016). Student Centric Curriculum Design and Implementation, Challenges \& Opportunities in Business Management \& IT Education. IRA International Journal of Education and Multidisciplinary Studies, 4(3), 423-437. DOI: http://dx.doi.org/10.21013/jems.v4.n3.p9.

[21] Alam, G. M., Hoque, K. E., Khalifa, M. T. B., Siraj, S. B., \& Ghani, M. F. B. A. (2009). The role of agriculture education and training on agriculture economics and national development of Bangladesh. African Journal of Agricultural Research, 4(12), 1334-1350.

[22] Kahne, J., \& Westheimer, J. (2003). Teaching democracy: What schools need to do. Phi Delta Kappan, 85(1), 34-66. DOI: https://doi.org/10.1177/003172170308500109.

[23] Hagquist, C., Starrin, B. (1997). Health education in schools-from information to empowerment models. Health promotion international, 12(3), 225-232. DOI: https://doi.org/10.1093/heapro/12.3.225.

[24] Brungardt, C. (1997). The making of leaders: A review of the research in leadership development and education. Journal of Leadership Studies, 3(3), 81-95. DOI: https://doi.org/10.1177/107179199700300309.

[25] Gururaj G Gouda, D’Mello Laveena, (2018). A Study on the Teacher-Student Relationship and its Impact on the Behaviour of High School Students. Exploring Avenues in Banking, Management, It, Education \& Social Sciences, 194- 200.

[26] Gururaj, G. Gouda, D’Mello Laveena, (2018). Introducing “Cap Concept” in a Class Room Learning for the Students to Achieve Success. Exploring Avenues in Banking, Management, IT, Education \& Social Sciences, ISBN No.: 978-93-5321-508-8, 179- 185.

[27] Aggarwal, Y. (2000). Public and private partnership in primary education in India. National Institute of Education Planning and Administration. DOI: http://www.dise.in/Downloads/Reports\&Studies/Public\%20Private\%20Partnership\%20in\%20In dia.pdf.

[28] Sriprakash, A. (2010). Child-centred education and the promise of democratic learning: Pedagogic messages in rural Indian primary schools. International Journal of Educational Development, 30(3), 297-304. DOI: https://doi.org/10.1016/j.ijedudev.2009.11.010.

[29] Samdal, O., Nutbeam, D., Wold, B., \& Kannas, L. (1998). Achieving health and educational goals through schools - a study of the importance of the school climate and the students' satisfaction with school. Health education research, 13(3), 383-397. DOI: https://doi.org/10.1093/her/13.3.383.

[30] Aithal, P. S. \& Suresh Kumar, P. M. (2016). Student Evaluation and Reforms in Higher Education Institutions. International Journal of Multidisciplinary Research and Modern Education (IJMRME), 2(1), 652-661. DOI:http://doi.org/10.5281/zenodo.160932. 
[31] Cohen, J. (2006). Social, emotional, ethical, and academic education: Creating a climate for learning, participation in democracy, and well-being. Harvard Educational Review, 76(2), 201237. DOI: https://doi.org/10.17763/haer.76.2.j44854x1524644vn.

[32] Starratt, R. J. (1991). Building an ethical school: A theory for practice in educational leadership. Educational administration quarterly, 27(2), 185-202. DOI: https://doi.org/10.1177/0013161X91027002005.

[33] D’Mello, Laveena, Monterio Meena. \& Pinto, Nelson, (2018). The quality of work life and job satisfaction of private sector employees. International Journal of Management, Technology and Social Sciences (IJMTS), 3(1), 11-17. 